\title{
KONSEP PENDIDIKAN AKHLAK PERSPEKTIF IMAM AL-GHOZALI; TELAAH KITAB IHYA ULUMUDDIN
}

\section{Najmi Faza}

Institut Dirosat Islamiyah Al-Amien Prenduan Sumenep Madura

najmifaza.1993@gmail.com

\begin{abstract}
Abstrak:
Krisis akhklak masih menjadi persoalan serius bangsa ini. Berbagai berita, baik yang dirilis media cetak maupun Elektronik, mewartakan semakin merosotnya moralitas anak bangsa. Itu bisa kita lihat dengan maraknya perkelahian atau tawuran entah antar manusiawi, maupun antar mahasiswa, seperti sudah membudaya, dan intensitasnya cukup tinggi. Dan tidak hanya pendidikan akhlak anak saja yang di perhatikan oleh imam Al-Ghazali melainkan pendidikan guru juga sangat diperhatikan oleh imam Al- Ghazali sehingga seorang guru pun harus menjadi contoh yang baik pada anak-anaknya. Dan agar guru tidak asal mendidik peserta didiknya dengan cara asal-asalan atau cara yang salah, yakni dalam pemberian sanksi atau hukuman lainnya. Salah satu komponen pendidikan yang mempunyai peran signifikan dalam dunia pendidikan adalah guru. Bagiamana konsep pendidikan akhalak menurut Imam Al-Ghazali dalam pembentukan akhlak yang positif bagi peserta didik? Usaha secara sungguh-sungguh dan berkelanjutan dalam mendorong jiwa masnuia untuk berakhlakul karimah, sehingga terbentuklah Akhlakaul karimah pada diri manusia tersebut. Tugas-tugas seorang peserta didik untuk membentuk akhlak yang positif, Mendahulukan kescuian jiwa dari akhlak yang hina dan sifat-sifat yang tercela. Karena ilmu adalah ibdahnya hati, shalatnya sir dan pendekatan batin kepada allah Ta'ala. belas kasih kepada orang-orang yang belajar dan memperlakukan mereka seperti memperlakukan anak-anaknya. segala sesuatu yang menjadi milikmu sebelum mati adalah masuk duniamu, kecuali ilmu, menjadi milikmu sebelum mati adalah masuk duniamu, kecuali ilmu, dan apa yang ada diatasnya.
\end{abstract}

Kata Kunci: Akhlak, Pemikiran, Kitab

\begin{abstract}
:
The moral crisis is still a serious problem for this nation. Various news, both published in print and electronic media, proclaim the declining morality of the nation's children. We can see that by the rise of fights or brawls, whether between humans or between students, as if it has become a culture, and the intensity is quite high. And it is not only the moral education of children that is noticed by Imam Al-
\end{abstract}


Ghazali but teacher education is also very much considered by Imam Al-Ghazali so that a teacher must also be a good example to his children. And so that teachers do not just educate their students in a perfunctory way or the wrong way, namely in giving sanctions or other punishments. One component of education that has a significant role in the world of education is the teacher. How is the concept of moral education according to Imam Al-Ghazali in the formation of positive morals for students? A serious and sustainable effort in encouraging the human soul to have good character, so that morality is formed in the human being. The duties of a student are to form positive morals, prioritize the purity of the soul from low morals and despicable traits. Because knowledge is the worship of the heart, the prayer sir and the inner approach to Allah Ta'ala. compassion for those who study and treat them as they would their children. Everything that belongs to you before death enters your world, except knowledge, what belongs to you before death is entered into your world, except knowledge and what is above it.

Keywords: Moral, Thought, Book

\section{Pendahuluan}

Krisis akhklak masih menjadi persoalan serius bangsa ini. Berbagai berita, baik yang dirilis media cetak maupun Elektronik, mewartakan semakin merosotnya moralitas anak bangsa. Itu bias kita lihat dengan maraknya perkelahian atau tawuran entah antar manusiawi, maupun antar mahasiswa, seperti sudah membudaya, dan intensitasnya cukup tinggi. Selain tawuran, tren pergaulan tanpa batas yang dibarengi seks bebas, bagi sebagian oknum anak bangsa sudah menjadi hal biasa entah itu di level sekolah menengah pertama, hingga bangku perguruan tinggi. Fenomena ini tanpa bukti. Jika anda ingin bukti, sekali waktu coba ana ketik di mesin pencari/search/ engine google.com. dalam hitungan detik anda akan di sodori aneka tampilan yang menjadi bukti degradasi moralitas anak bangsa. ${ }^{1}$

Perbuatan anak-anak muda yang nyata-nyata bersifat melawan hukum dan anti sosial tersebut pada dasarnya tidak di sukai oleh masyarakat, di sebut juga problem sosial. Jadi pada dasarnya problema-problema sosial menyangkut nilainilai sosial dan moral, oleh karena manyangkut tata kelakuan yang immoral, berlawanan dengan hukum dan bersifat merusak. ${ }^{2}$

Semua anak usia 10 sampai 13 tahun mengucapkan kata-kata kotor sesekali. Mereka mengutuk seperti orang dewasa, untuk melepaskan rasa frustasi, kemarahan atau rasa nyeri yang mendadak. Mereka menggunakan kata-kata umpan kala bersama temennya sebagai cara untuk menjadi bagian kelompok itu atau untuk berlaku supaya terlihat dewasa, adalah hal yang mudah untuk mudah belajar katakata umpatan, mereka bias mendengar dari TV, CD Film, temen sebaya dan orang tua. $^{3}$

\footnotetext{
${ }^{1}$ Agus Wibowo, Gunawan, Pendidikan Karakter Berbasis Kearifan Lokal Di sekolah, (Yogyakarta: 2015), 1.

2 Sudarsono, Kenakalan Remaja: Prevensi, rehabilitasi, dan resosialisasi, (Jakarta: 2012), 114.

3 Ronald C. Heagy MSW, Dunia Yang Mulai Liar, (Jakarta: 2006), 39.
} 


\section{DIROSAT \\ Journal of Islamic Studies \\ Volume 6, No. 22021}

ISSN: 2541-1667 (print); 2541-1675 (online)

Di kalangan anak didik, pendidikan akhlak cenderung terabaikan, bahkan seringkali tidak menjadi titik tekan dalam setiap lembaga-lembaga pendidikan sekolah. Persoalan ini muncul akibat kurangnya perhatian tenaga pendidik dab keluarga dalam menanamkan nilai-nilai akhlak dalam setiap perilaku kehidupan sehari-hari. ${ }^{4}$

Anak-anak pra remaja dan awal masa remaja sangat tertarik dengan pembahasan seks. Anak-anak merasa lebih nyaman dan tidak tertekan berbicara dengan temen mereka tentang seks. Mereka juga mencari informasi dari kakak, buku, TV, Film, dan majalah. Sebagian memperolah infromasi akurat, sebagian lain tidak. Anak-anak jarang mendengar pembahasan nilai dari sumber yang bukan orang tua. ${ }^{5}$

Ditengah carut marut dan centang perenang dunia pendidikan Indonesia yang diwarnai dari berderet kasus asusial,pencabulan, kasus foto dan video porno yang diproduksi oleh dunia pendidikan Indonesia. Menandai gagalnya sistem pendidikan akhlak dan moral bangsa Indonesia.

Mengapa bisa sedemikian parah wajah pendidikan di Indonesia? Ya...bangsa ini memang bisa dikatakan berhasil mendidik anak bangsa menjadi orang yang cerdas atau sedikit cerdas, tetapi gagal mendidik anak bangsa menjadi orang yang berakhlak dan bermoral.

Mengapa ini terjadi? Negara ini menganggap bahwa kemajuan pendidikan hanya dari segi kecerdasan otak saja. Sedangkan pendidikan moral dan akhlak yang menyangkut kepada pendidikan agama sangat kurang dan hampir tidak terpikirkan oleh pemerintah. Inilah yang membuat akhlak dan moral anak bangsa hancur.

Mungkin sebahagian dari kita mengalaminya, waktu di sekolah dulu berapa jam pelajaran agama yang kita peroleh di Sekolah. Sedangkan pendidikan agama untuk anak-anak tanggung jawabnya diberikan kepada keluarga masing-masing. Inilah ciri dari pendidikan sekuler dan inilah hasilny. Untuk apa orang pandai tetapi tidak berakhlak.

Solusi yang ditawarkan Indonesia banyak mengadopsi sistem pendidikan sekuler, inilah yang membuat hancur pendidikkan di Indonesia terutama pendidikan akhlak dan moral. Indonesia harus mengembangkan pola pendidikan asli dari Indonesia sendiri yaitu pesantren.

Jika dikelola dan dikembangkan dengan baik dan didukung oleh pemerintah, maka pola pesantren ini sangat baik dalam mendidik moral dan akhlak anak-anak ketika menimba ilmu.

Disiplin yang keras dan pengawasan anak-anak selama 24 jam melatih moral dan akhlak untuk selalu disiplin dan terbiasa mematuhi aturan yang ada. Sudah banyak yang merasakan manfaat sistem pesantren ini. Memang ada yang gagal dan itu sebagaian kecil saja, karena pastilah tidak semua benih yang ditanam akan berhasil.

Sistem barat mengadopsi pesantren dengan menjalankan sistem asrama bagi pelajar dan siswanya yang diawasi sangat ketat, dan mereka berhasil. Sayangnya

\footnotetext{
${ }^{4}$ Mohammad takdir ilahi, Gagalnya pendidikan Karakter (Yogyakarta: 2014), 29.

${ }^{5}$ Ibid, 62 .
} 
sistem pesantren ini hanya diadakan sampai tingat pendidikan menengah atas saja. Untuk tingkat pendidikan tinggi sistem pesantren ini tidak dikembangkan. Hal ini menyebabkan anak didik yang biasa terawasi menjadi lepas kendali setelah mereka masuk ke dunia pendidikan tinggi.

Kurangnya pemerataan pendidikan di Indonesia juga menjadi penyebab rusaknya moral dan akhlak bangsa. Hal ini lah yang menyebabkan bahwa perbandingan orang-orang yang terdidik dengan akhlak yang baik sangat sedikit dibanding dengan rakyat yang tidak terdidik dengan akhlak yang rusak.

Menghilangkan image bahwa pesantren hanya untuk mendidik anak buangan atau anak yang bandel atau anak yang telah rusak akhlaknya. Sedangkan anak yang tidak bermasalah tidak mau bersekolah di pesantren. Jika anak bermasalah saja bisa dibuat baik, konon lagi anak yang baik akan semakin menjadi baik jika mau bersekolah di pesantren.

Semoga pendidikan Indonesia tidak hanya memajukan kecerdasan bangsa tapi juga memajukan moral dan akhlak bangsa. ${ }^{6}$

Perkembangan zaman selalu menimbulkan tantangan-tantangan, yang sebagiannya sering tidak dapat diramalkan sebelumnya. Sebagai konsukuensi logis pendidikan selalu di hadapkan pada masalah-masalah baru. Masalah yang di hadapi dunia pendidikan itu demikian luas, Pertama karena sifat sasarannya yaitu manusia sebagai makhluk yang unik, Kedua karena usaha pendidikan harus mengantisipasi ke hari depan yang tidak segenap seginya terjangkau oleh kemampuan daya ramal manusia. Oleh karena itu, perlu ada rumusan sebagai masalah-masalah pokok yang dapat di jadikan pegangan oleh pendidikan dalam mengemban tugasnya. ${ }^{7}$

Pendidikan pada hakikatnya merupakan proses humanisasi kepada anak didik yang sedang dalam proses memahami diri dan lingkungannya. Sebagai proses humanisasi pendidikan hendaknya menempatkan anak didik sebagai subjek yang memilki individulitas yang unik dan khas dalam pertumbuhan fisik, perkembangan intelektual, emosional dan spiritual. Oleh karena itu, anak didik perlu mendapatkan kesempatan dan keleluasaan untuk mengembangkan segala potensi yang dimilikinya. Dalam proses pembelajaran khususnya di sekolah perlu diciptakan situasi kondisi yang memungkinkan anak belajar dalam suasana menyenangkan, menggairakan, demokratis dan saling menghargai. ${ }^{8}$

Sebagai lembaga pendidikan sekolah di tuntut mampu mewujudkan cita-cita pendidikan yang paling luhur yakni menjadikan manusia sebagai manusia yang sesungguhnya. Manusia sesungguhnya adalah manusia yang menyadari dirinya sebagai actor yang aktif, penentu dan bertanggung jawab terhadap segala peristiwa dari dalam keseluruhan peristiwa dunia. Dengan demikian, sekolah sesungguhnya menjadi tempat untuk mengembangkan budaya santun, demokrasi, bertindak adil dan tidak deskriminatif kepada seluruh warga sekolah terutama peserta didik. ${ }^{9}$

\footnotetext{
${ }^{6}$ https://infotekkom.wordpress.com/2009/05/02/hardiknas-kegagalan-pendidikan-akhlak-danmoral-bangsa/4/03/2018/12:38.

${ }^{7}$ Ramayulis, Dasar-Dasar Kependidikan, (Jakarta: 2015), 281.

8 M. Djamal, Fenomena Kekerasan di Sekolah, (Yogyakarta: 2016), 1.

${ }^{9}$ Ibid, 3.
} 
Menurut analisis Tilaar ada hal yang mendasar jika melihat hubungan antara pendidikan dengan budaya pada era orde lama dengan orde baru. Pada orde lama ketika itu pendidikan merupakan bagian gerakan politik untuk menggalang kekuatan rakyat antara lain, di dalam perang dingin dan perang dalam mewujudkan integritas bangsa. Pendidikan di jadikan sebagai alat politik, baik dalam arti yang negative maupun positif. Dalam kerangka ini dilahirkannya konsep panca wardana yang berarti lima program pendidikan, untuk mencapai tujuan politik saat itu. Pandangan ini secara sepintas bersifat parsial akan tetapi untuk kepentingan politik saat itu sangat baik. Sedangkan pada masa orde baru, tampak pendidikan tidak lagi di arahkan kepada perkembangan pribadi yang mandiri dan kritis akan tetapi mulai tunduk kepada proses indoktrinasi. Walaupun dalam perkembangannya ada proses indoktrinasi, akan tetapi ada beberapa kebijakan tentunya patut mendapatkan apresiasi. ${ }^{10}$

Dalam perkembangannya, tujuan, orientasi dan sistem penyelenggara pendidikan di Indonesia telah mengalami beberapa kali perubahan. Pada awal kemerdekaan antara tahun 1945-1968 misalnya pendidikan cenderung diorientasikan pada usaha penanaman semangat dan patriotism. Pada saat itu yang menjadi prioritas kebutuhan bangsa Indonesia adalah penumbuhan rasa kebangsaan persatuan, dan semangat membangun bangsa yang lepas dari kungkungan kolonialisme, imperialism, dan feodalisme. Implikasinya, politik pendidikan di tekankan pada pengambangan dan penguatan "national and character building" serta penyelenggaraan pendidikan diorganisir secara terpusat. ${ }^{11}$

Pendidikan mencakup seluruh proses hidup dan segenap bentuk interaksi manusia dengan lingkungannya dalam rangka mengembangkan potensi yang terdapat dalam dirinya sesuai dengan tahapan perkembangan secara optimal sehingga mencapai suatu taraf kedewasaan tertentu. Pendidikan merupakan kebutuhan mendasar bagi perkembangan kepribadian. Di satu sisi, pendidikan dapat membentuk kepribadian seseorang dan dapat diakui sebagai kekuatan yang dapat menentukan prestasi dan produktivitas seseorang. Dengan bantuan pendidikan, seseorang memahami dan mengintepretasikan lingkungan yang dihadapi sehingga ia mampu menciptakan karya yang gemilang dalam hidupnya. Dengan kata lain, melalui pendidikan, manusia dapat mencapai suatu peradaban dan kebudayaan yang tinggi. Dari perspektif ini, Islam hadir menempatkan pendidikan akhlak pada kedudukan yang penting dan tinggi. ${ }^{12}$

Pendidikan islam dipengaruhi oleh multifactor, kondisi, dan problem yang kompleks. Maju mundurnya teori dan praktik pendidikan islam diakibatkan oleh kompleksitas problem tersebut. Problem dimaksud berupa segala persoalan yang inhern dalam pendidikan, yakni problem internal, maupun yang berada di luar jangkuan bidang pendidikan, yakni problem eksternal yang secara tak langsung berpengaruh, seperti masalah pengangguran, kemiskinan, etos kerja, stabilitas politik, lemhanya penegakan hokum dan lain-lain. ${ }^{13}$

\footnotetext{
${ }^{10}$ Anwar Hafid, Jafar Ahiri, Pendais Haq, Konsep Dasar Ilmu Pendidikan, (Bandung: 2014), 98.

${ }^{11}$ Nurhattati Fuad, Manajemen Pendidikan Berbasis Masyarakat, (Jakarta: 2014), 3.

12 Ibid, 182.

${ }^{13}$ Abd. Rachman Assegaf, Filsafat Pendidikan Islam, (Jakarta: 2011), 19.
} 
Ke manakah arah pendidikan islam di masa depan harus di bawa? Sebuah pertanyaan klasik yang sering muncul tetapi sekaligus menentang bagi para civitas akademikanya untuk selalu memberikan jawabannya. Entah siapa yang salah, hingga saat ini, masyarakat masih mempunyai persepsi kurang menguntungkan terhadap pendidikan islam. Faktanya, masih banyak pilihan orang tua memasukkan anaknya ke pendidikan islam sebagai pilihan kedua setelah pilihan pertama ke lembaga umum. ${ }^{14}$

Kebangkitan umat Islam tidak hanya dipahami dan diawali dengan memberikan perhatian sepenuhnya terhadap pengadaan sarana pendidikan. Yang lebih penting dari itu adalah bagaimana melakukan pembenahan tentang konsepsi ilmu pengetahuan yang selaras dengan nilai-nilai Islam. ${ }^{15}$

Ki Hajar Dewantara mengungkapkan dengan jelas bahwa salah satu tujuan pendidikan adalah memajukan moral atau karakter bagi para peserta didik demi tercapainya kehidupan yang selaras. Akan tetapi, hingga saat ini pendidikan yang mengedepankan nilai kognitif masih menjadi idola bagi sebagian masyarakat Indonesia. Padahal, pendidikan yang terlalu mementingkan pada pengejaran kecerdasan intelektual atau cognitive ansich tanpa diimbangi dengan kecerdasan moral hanya mampu melahirkan orang-orang yang cerdas secara intelektual tetapi tidak mampu untuk memberikan kedamaian dan keadilan di tengah-tengah masyarakat Pendidikan sebagai upaya perubahan yang menyangkut aspek kehidupan manusia memerlukan referensi-referensi sebagai sumber serta acuan dalam menjalankan prosesnya2 serta untuk mencapai tujuan yang dicitacitakannya. ${ }^{16}$

Pendidikan akhlak mulia secara historis merupakan respon terhadap adanya kemerosotan akhlak pada masyarakat dengan karakter budaya kota, yaitu masyarakat yang cenderung ingin serba cepat, tergesa-gesa, pragmatis, hedonistik, materialistik, penuh persaingan yang tidak sehat, permissive, mengambil keputusan serba cepat, dan menghadapi berbagai masalah: sosial, ekonomi, politik, budaya, ilmu pengetahuan dan sebagainya. Masyarakat yang hidup dalam karakter budaya kota tersebut merupakan perhatian utama pendidikan akhlak. ${ }^{17}$

Dalam pendidikan akhlak menempati posisi yang penting, baik secara konseptual maupun praktis. Di dalamnya ada banyak kandungan normative keislaman dan teladan dari para tokoh penebar kebaikan. Tidak heran jika islam sangat memperahatikan akhlak dan menempatkannya sebagai bidang penting pendidikan. Bahkan dapat menjadi pondasi yang vital dalam bentuk manusia yang berkahlak mulia. Sehingga pada saatnya, manusia dapat menepati tingkah lakunya secara arif dan bijaksana serta didukung pengetahuan keislaman yang mendalam.

\footnotetext{
14 Ibid, 249.

15 Roziq Syaifuddin, Epistomologi Pendidikan Islam dalam kacamata Al-Ghazali dan Fazlur Rahman, (Makalah File PDF, UIN Maulana Malik Ibrahim Malang: 2012), 328.

16 M. Syamsul Ma'rif, Nilai-nilai Akhlak Dalam Suluk Linglung Dan relevansinya dengan pendidikan islam, (Jurnal Empirisma: 2015), 168.

17 Devi Arisanti, Implementasi Pendidikan Akhlak Mulia Di SMA Setia Dharma Pekanbaru, (Jurnal AlThariqah, Fakultas Tarbiyah dan Keguruan UIN Suska Riau: 2017), 208.
} 
Tapi realitas di zaman sekarang sangat minim akan akhlak yang mulia dan karakter yang bagus. ${ }^{18}$

Karenanya, islam juga memiliki perhatian terhadap masa-masa pertumbuhan manusia sejak ia kecil, remaja, dewasa, dan pada saatnya memiliki tanggung jawab sepenuhnya baik terhadap dirinya maupun keluarganya. Menurut banyak kalangan, masak anak-anak merupakan fase yang berpotensi untuk menerima norma-norma dan secara afektif mempratekkan pengetahuan-pengetahuan secara sederhana.

Imam Al-Ghazali memanfaatkan metode pendidikan akhlak anak dalam bentuk nasehat-nasehat yang bersifat normatif. ${ }^{19}$

Salah satu faktor yang sangat penting dalam pendidikan adalah guru. Karena guru itulah yang akan bertanggung jawab dalam pembentukan pribadi anak didiknya terutama pendidikan agama ia mempunyai pertanggungjawaban yang lebih berat. Karena selain bertanggung jawab terhadap pembentukan pribadi anak yang sesuai dengan ajaran Islam, ia juga bertanggung jawab terhadap Allah SWT. Karena alasan-alasan yang telah ada maka perlu adanya perbaikan-perbaikan dalam segala bidang pendidikan khususnya pendidikan agama. Pendidikan harus mampu melahirkan manusia yang aktif, kreatif, inovatif dan mandiri sehingga mampu menandingi dampak persaingan global. Guru dalam konteks kependidikan mempunyai peranan yang besar dan strategis. 20

Maka dari permasalahan pendidikan akhlak tersebut diperlukan lah sebuah konsep pendidikan akhlak yang baik, karena jika konsep pendidikan konsepnya baik maka kualitas pendidikan akhlak yang akan selanjutnya menjadi lebih baik dari sebelum-sebelumnya dan dapat di aplikasikan di dunia pendidikan karena dengan pendidikan akhlak peserta didik akan memiliki akhlak yang postif dan baik.

\section{Metode Penelitian}

Karena objek penelitian ini adalah tentang Konsep pendidikan akhlak atau karakter menurut Imam Ghozali, maka pendekatan penelitian ini menggunakan pendekatan kualitatif dengan jenis penelitin Deskriptif, maksudnya adalah dengan memberikan deskripsi atau gambaran mengenai objek kajian teks yang bersangkutan secara teliti tanpa membuat uraian pribadi.

Penelitian kepustakaan adalah suatu cara untuk mengadakan penelitian berdasarkan naskah, yang di terbitkan baik melalui kitab-kitab, jurnal-jurnal, majalah, maupun buku-buku yang sesuai dengan pembahasan penelitian, sehingga dapat dijadikan acuan dalam penulisan. Penelitian yang peneliti lakukan dengan menggunakan kitab Ihya Ulumuddin terjemahan, di karenakan kurangnya kemampuan peneliti dalam menerjemahkan kitab.

Data merupakan sumber informasi yang didapatkan oleh peneliti melalui penelitian yang dilakuakan. Data yang di peroleh nantinya akan diolah sehingga menjadi informasi baru yang dapat dimanfaatkan oleh pembacanya. Dalam

\footnotetext{
18 Ibid, 2.

19 Ibid, 3.

${ }^{20}$ Muslimin, Problematika Pembelajaran Pendidikan Agama Islam dan Upaya Solusi Guru Agama Dalam pembinaannya di Sekolah, (Jural Ilmiah Pendidikan STAI Syekh maulana Qori Jambi: 2017), 206.
} 


\section{DIROSAT \\ Journal of Islamic Studies \\ Volume 6, No. 22021}

ISSN: 2541-1667 (print); 2541-1675 (online)

penelitian ini, data diperoleh melalui dua sumber yaitu data primer dan data skunder.

Data primer adalah sumber informasi yang secara langsung berkaitan dengan tema yang menjadi pokok bahasan dalam penelitian. Adapun data primer dalam peneltian ini adalah: kitab Ihya Ulumiddin karangan Imam Al-Ghozali.

Data sekunder adalah sumber informasi yang berkaitan dengan tema yang menjadi pokok bahasan, dengan kata lain data sekunder adalah data penunjang yakni: Buku Filsafat Pendidikan Al-Ghozali, Filsafat Pendidikan Islam, Biografi Imam Al-Ghozali.

Adapun teknik pengumpulan data yang peneliti lakukan dalam penelitian ini adalah: Tinjauan sumber data primer yakni kitab Ihya Ulumiddin, pedoman konsep pendidikan akhlak atau karakter menurut Imam Al-Ghozali. Dalam hal ini peneliti mengkaji Konsep pendidikan akhlak atau karakter menurut Imam Al-Ghozali dalam pembentukan akhlak atau karakter yang positif pada peserta didik.

Kemudian peneliti membaca buku (sekunder) yang berkaitan dengan pembahasan yang akan di teliti secara komperhenship. Peneliti menguraikan secara teratur konsep pendidikan akhlak atau karakter menurut Imam Al-Ghozali dalam pemebentukan karakter yang positif pada peserta didik.

Dalam penelitian ini, peneliti menggunakan analisis data taksonomi (Taxonomy analysis). Pada tahap analisis taksonomi, peneliti berupaya memahami domain-domain tertentu sesuai fokus masalah atau sasaran penelitian. Masingmasing domain mulai dipahami secara mendalam, dan membaginya lagi menjadi sub-domain, dan dari sub-domain itu di rinci lagi menjadi bagian-bagian yang lebih khusus lagi hingga tidak ada lagi yang tersisa, alias habis (Exhausted). Pada tahap analisis ini peneliti bias mendalami domain dan sub-domain yang penting lewat konsultasi dengan bahan-bahan pustaka untuk memperoleh pemahaman lebih dalam. ${ }^{21}$

\section{Pembahasan dan Hasil Penelitian}

\section{Tinjauan tentang pengertian Pendidikan Akhlak.}

Pendidikan akhlak adalah Suatu usaha yang dilakukan dengan sadar untuk menanamkan keyakinan dalam lubuk hati seseorang, guna mencapai tingkah laku yang baik dan terarah serta menjadikan sebagai suatu kebiasaan baik menurut akal maupun syara'. Maka jelas sebuah pendidikan akhalak sangat lah penting bagi setiap orang tidak hanya seorang peserta melainkan seorang pendidik pun harus tetap belajar dan mencari pendidikan agar dia anggap oleh orang-orang sekitrnya.

Menurut Imam Al Ghazali, lafadz khuluq dan khalqu adalah dua sifat yang dapat dipakai bersama. Jika menggunakan kata khalqu maka yang dimaksud adalah bentuk lahir, sedangkan jika menggunakan kata khuluq maka yang dimaksud adalah bentuk batin. Karena manusia tersusun dari jasad yang dapat disadari adanya dengan kasat mata (bashar), dan dari ruh dan nafs yang dapat disadari adanya dengan penglihatan mata hati (bashirah), sehingga kekuatan nafs yang adanya

\footnotetext{
21 Mohammad Rusli, Metode Penelitian Kuantitatif dan Kualitatif Berorientasi praktis, (Sumenep: 2013), 276.
} 
disadari dengan bashirah lebih besar dari pada jasad yang adanya disadari dengan bashar. Sesuai dengan hal ini Imam Al-Ghazali Mengutip sabda Allah SWT yang terdapat dalam Al-Qur'an: Artinya:

(Ingatlah) ketika Tuhanmu berfirman kepada malaikat: "Sesungguhnya Aku akan menciptakan manusia dari tanah". Maka apabila Telah Kusempurnakan kejadiannya dan Kutiupkan kepadanya roh (ciptaan) ku; Maka hendaklah kamu tersungkur dengan bersujud kepadanya". (QS. Al Shaad: 71-72).22

Imam Ghazali, seorang ahli filosofi terbesar sejak dari zamannya dulu hingga saat ini, mengatakan demikian:

"Seorang anak, sejak ia di lahirkan itu adalah merupakan amanat atau titipan dari tuhan kepada kedua orang tuanya. Kalbu anak itu masih bersih dan suci, bagaikan suatu permata yang maha berharga, sunyi dari segala macam lukisan dan gambaran. Mana kala anak itu dibiasakan kepada hal yang baik, di perlihatkan kepadanya halhal yang baik, bagus dan pula sekaligus di ajarkan serta di perintah mengamalkannya, maka anak itu akan tumbuh menjadi manusia, makin hari besar dan makin tertancap serta makin meresaplah kebaikan-kebaikan itu dalam jiwanya. Denga demikian tidak perlu diasingkan lagi bahwa anak itu akan memperoleh kebahagiaan di dunia dan akhirat. Kedua orang tuanyapun memperoleh pahala juga karena dengan susah payah megisikan didikan yang mulia itu dalam kalbu anaknya. Bahkan bukan hanya ayah dan ibunya saja, tetapi juga semua guru dan pendidik-pendidiknya. Sebaliknya, jikalau semula sudah di beri didikan yang buruk, atau dilengahkan sama sekali soal tarbiyahnya, maka akibatnya anak itu pun akan celaka dan binasa, sedang di kalangan masyarakat sama sekali tidak ada harga dan nilainya. Manakala sudah demikian keadaan anak itu, maka siapakah yang berdosa dan siapakah yang wajib memikul tanggung jawabnya? Tentu saja pelakunya sendidi, yakno anak yang binal itu, namun manusia yang paling besar salah dan yang terbanyak dosanya ialah orang yang menjadi pengasuhnya, apakah itu orang tunya sendiri ataukah walinya ataupun siapa saja yang memperoleh penyerahan untuk memberikan asuhan dan pendidikan kepada anak itu". ${ }^{23}$

Pendidikan moral Imam al-Ghazali adalah menghilangkan akhlak yang buruk dan menanamkan akhlak yang baik. Imam al-Ghazali berpendapat bahwa adanya perubahan-perubahan akhlak bagi seseorang adalah bersifat mungkin, misalnya dari sifat kasar kepada sifat kasihan. Disini al-Ghazali membenarkan adanya perubahan-perubahan keadaan terhadap beberapa ciptaan Allah, kecuali apa yang menjadi ketetapan Allah seperti langit dan bintang-bintang. Sedangkan pada keadaan yang lain, seperti pada diri sendiri dapat diadakan kesempurnaannya melalui jalan pendidikan. Menghilangkan nafsu dan kemarahan dari muka bumi sungguh tidaklah mungkin, namun untuk meminimalisir keduanya sungguh menjadi hal yang mungkin dengan jalan menjinakkan nafsu melalui beberapa latihan rohani. Imam al-Ghazali membagi struktur kerohanian manusia menjadi

\footnotetext{
22 Al Qur an, Surah As Shaad ayat 71-72

${ }^{23}$ Moh. Abdai Rathony, Idzotun Naasyi'in, (Semarang: 1976), 313-314.
} 
empat unsur, yaitu nafs, qalb, ruh dan akal. Keempat unsur tersebut masing-masing mempunyai dua arti, yaitu arti umum dan khusus. ${ }^{24}$

Menurut Ratna Megawangi pendidikan akhlak adalah sebuah usaha untuk mendidik anak-anak agar dapat mengambil keputusan dengan bijak dan mempraktikannya dalam kehidupan sehari-hari, sehingga mereka dapat memberikan kontribusi yang positif kepada lingkungannya. Adapun pendidikan karakter menurut musfiroh adala sesuatu sistem penanaman nilai-nilai karakter kepada warga sekolah, yang meliputi komponen pengetahuan, kesadaran ataupun kemauan, dan tindakan untuk melaksanakan nilai-nilai tersebut. ${ }^{25}$

Pendidikan akhlak adalah salah pendidikan yang wajib diberikan kepada anak dari sejak usia dini. Hal ini dikarenakan pada usia tersebut anak masih suci dan bersih dan belum terkontaminasi dengan berbagai peragai buruk. Oleh karena itu, sebagai pendidik dan orang tua perlu mengajarkan dan mencontohkan perbuatanperbuatan yang mulia yang sesuai dengan ajaran al-quran dan hadist nabi Muhammad SAW. ${ }^{26}$

Pendidikan akhlak adalah suatu proses pembelajaran yang dilakukan secara sadar oleh orang dewasa kepada peserta didik dengan mentransfer nilai-nilai moral dan pembiasaan-pembiasaan yang baik dengan tujuan agar peserta didik mampu memiliki akhlak yang mulia (al-akhlak al-karimah) dan berkepribadian yang kamil (sempurna) sesuai dengan ajaran Islam. ${ }^{27}$

Sebagaimana dijelaskan oleh Asmawati Suhid (2005) bahawa Al-Ghazali juga menekankan maksud pendidikan ialah menanam perangai baik dalam diri kanakkanak supaya mereka "dapat menilai antara yang benar dan yang salah". Hal ini disokong pula oleh pandangan Syed Muhammad Naquib Al-Attas (1980) yang menegaskan bahawa pendidikan merupakan proses penerapan adab ke dalam diri seseorang. Tegasnya, menurut perspektif Islam, pendidikan memainkan peranan penting dalam melahirkan insan yang berakhlak dan bermoral. ${ }^{28}$

Dalam pengertian sederhana, menurut Muclas Samani dan Hariyanto, pendidikan karakter adalah hal positif apa saja yang dilakukan guru dan berpengaruh kepada siswa yang diajarnya. Muclas Samani dan Hariyanto mengutip Winton bahwa pendidikan karakter adalah upaya sadar dan sungguh-sungguh dari seorang guru untuk mengajarkan nilai-nilai kepada para siswanya. Pendidikan karakter telah menjadi sebuah pergerakan pendidikan yang mendukung pengembangan sosial, pengembangan emosional, dan pengembangan etik para

\footnotetext{
${ }^{24}$ Didi Supardi, Abdul Ghofur, Mahbub Nuryadien, Konsep Pendidikan Moral Imam Al-Ghpzali dan Relevansinya dengan Pendidikan Agama Islam Di Indonesia, (Jurnal Al Tarbawi Al Haditsah IAIN Syekh Nurjati Cirebon: 2016), 5.

25 Dharma kesuma, Cepi Triatna, Johar pernama, Pendidikan Karakter kajian teoritik dan Praktik di sekolah, (Bandung: 2013), 5.

${ }^{26}$ Herawati, Pendidikan Akhlak Bagi Aanak Usia Dini, (Jurnal Pendidikan Islam UIN Ar-Rainy Banda Aceh: 2017), 128.

27 Muchtar, Konsep Pendidikan Akhlak dan Dakwah dalam Perspektif Dr. KH. Zakky Mubarak, MA, (Jurnal Studi Al-Qur'an; Membangun Tradisi Berfikir Qur'ani STAI Nahdhlatul Ulama Jakarta: 2016), 199.

${ }^{28}$ Asmawati Suhid, Pengajaran Adab \& Akhalak Islam Dalam Membangunkan Modal Insan, (Jurnal Pengajian Umum Bil, Universiti Putra Malaysia: 2016), 169.
} 


\section{DIROSAT \\ Journal of Islamic Studies \\ Volume 6, No. 22021}

ISSN: 2541-1667 (print); 2541-1675 (online)

siswa. Merupakan suatu upaya proaktif yang dilakukan baik oleh sekolah maupun pemerintah untuk membantu siswa untuk mengembangkan inti pokok dari nilainilai etik dan nilai-nilai kinerja, seperti kepedulian, kejujuran, kerjinan, sportifitas, keuletan dan ketabahan, tanggung jawab, menghargai diri sendiri dan orang lain. ${ }^{29}$

\section{Tata kesopanan atau akhlak seorang peserta didik}

Akhlak seorang peserta didik apabila ingin membentuk akhlaknya menjadi positif yaitu dengan pembiasaan dan pelatihan serta peneladanan dan peniruan. Pembiasaan bisa dilakukan sejak usia dini yaitu dengan sikap dan berprilaku yang baik, sopan dan menghormati orang lain. Sedangkan pelatihan dapat diaplikasikan dengan menjalankan ibadah bersama keluarga seperti sholat, puasa dan latihanlatihan yang lainnya. Peneladanan dan peniruan bisa dilakukan oleh orang yang dianggap sebagai panutan baik orang tuanya sendiri, guru-gurunya ataupun tokoh lain yang layak dijadikan figure yang mana pernyataan ini dikemukakan oleh ulama yang terkenal yaitu Ibnu Maskawih.

Pada penjelasan yang lain yang di jelaskan oleh imam Al-Ghozalil yaitu, seorang peserta didik haruslah mendahulukan kescuian jiwa dari akhlak yang hina dan sifat-sifat yang tercela. Karena ilmu adalah ibdahnya hati, shalatnya sir dan pendekatan batin kepada allah Ta'ala. Sebagaimana shalat yang menjadi tugas anggauta-anggauta badan yang lahir itu tidak shah kecuali dengan membersihkan/mensucikan lahir dari hadts-hadts dan kotoran-kotoran maka demikian juga ibadah batin dan meramaikan hati denga ilmu itu tidak shah kecuali setelah mensucikannya dari akhlak yang kotor dan sifat-sifat yang najis. Nabi Saw bersabda:

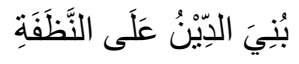

Artinya: "Agama itu dibina atas kebersihan".

Dari penjelasan diatas peneliti mempunyai sebuah Korelasi untuk membentuk akhlak yang positif pada peserta didik yaitu dengan mendahulukan kesucian jiwa dari akhlak yang hina dan sifat yang tercela dengan pelaithan yang dapat diaplikasikan secara langsung yaitu dengan menjelankan ibadah bersama kelurga seperti sholat, puasa dan latihan-latihan yang lainnya agar jiwa seorang peserta didik bersih dari hadats-hadats dan kotoran yang menyebabkan dan berdampak negatif pada akhlak peserta didik.

Al Qadhi Fahruddin adalah seorang imam di daerah Marwa yang sangat dihormati oleh para pejabat Negara:

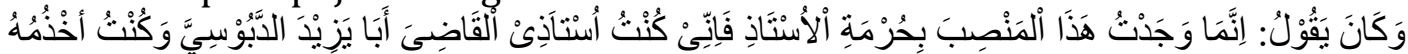

$$
\begin{aligned}
& \text { وَأَطْبَخُ طَعَا مُهُوْ لَا اَكُلُ مِنْهُ }
\end{aligned}
$$

${ }^{29}$ Ibid, 8 
Beliau berkata, "Aku mendapat kedudukan ini karena aku menghormati guruku, abi yazid addabusi. Aku selalu melayani beliau, memasak makanannya, dan aku tak pernah ikut makan bersamanya"

Tidak sombong karena ilmu dan tidak menentang guru namun ia serahkan kendali urusannya kepada guru itu secara keseluruhan dalam setiap rincian, dan mendengarkan nasihatnya seperti orang yang sakit dan bodoh mendengarkan dokter yang sayang dan cerdik.

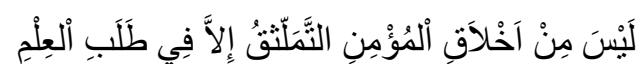

Artinya:Bukan dari akhlak mu'min itu merendahkan/menghinakah dari kecuali dalam mencari ilmu.

Maka sebagai seorang peserta didik yang mempunyai akhlak yang positif atau berakhlakul karimah tentu tidak boleh memiliki sifat yang sombong, berprilaku kasar atau berkata-kata yang kurang sopan apabila ingin mendapatkan ilmu yang bermanfaat dari seorang guru.

Nashih Ulwan memberikan arahan para pendidik agar memperhatikan tiga poin penting dalam rangka membina peserta didik dalam pembentukan akhlak atau karakter Islami yang tangguh dan dapat diaplikasikan di dalam manajemen pembinaan peserta didik di lembaga-lembaga Islam yaitu Mencegah peserta didik dari Tasyabuh, mencegah peserta didik dari istighraq, melarang peserta didik dari mendengarkan msuik dan al-Ghina Al-Khali (Lagu erotis), di zaman sekarang apabila hanya pencegahan dan larangan sudah dilakukan namun masih mepunyai kekurangan yaitu Press on a heart (Penekanan Bathin).

Berbeda dengan yang dipaparkan oleh imam Al-Ghozali yang mana peerta didik harus mempunyai tujuan untuk menghiasi dan mengindahkan dengan memulai penekanan bathin untuk mendekatkan diri kepada allah swt, bertetangga dengan kelompok yang tinggi dari para malaikat dan orang-orang yang didekatkan (kepada allah). Dan dengannya (ilmu) ia tidak bermaksud untuk memperoleh kepemimpinan, harta dan pangkat, berdebat dengan orang-orang bodoh dan berbangga terhadap teman-teman dengan memiliki akhalak yang positif.

Adapun akhlak kepribadian yang stabil yaitu: pertama, mampu mengendalikan emosi. Salah satu tolak ukur kepribadian yang stabil adalah kematangan emosi. Semakin matang emosi seseorang akan kian stabil pula kepribadiannya. Kedua, mampu menumpuk kepercayaan diri. Kepercayaan diri menentukan kualitas hidup seseorang, dan ini juga merupakan salah satu tolak ukur kepribadian. Ketiga, Mampu bersosialisasi dan beradaptasi jangan pula mengabaikan kemampuan bersosialisasi.

Orang yang baru menerjunkan diri dalam ilmu pada awal langkahnya agar menjaga diri dari dengarkan pendapat manusia yang berbeda-beda. Baik ia menejunkan dari dalam ilmu-ilmu dunia maupun ilmu-ilmu akhirat. Karen hal itu membingungkan akalnya, membingungkan benaknya, membuat-buat pendapatnya dan memutus asakannya dari mengetahui dan menelitinya.

Peserta didik apabila sudah memeilki akhlak yang positif dia mengawali langkahnya dengan menjaga pendengarannya tentang pendapat manusia yang berbeda-beda kerena dengan seperti itu peserta didik akan lebih bisa mengendalikan emosi, dikarenakan menjadi peserta didik maka terkadang 


\section{DIROSAT \\ Journal of Islamic Studies \\ Volume 6, No. 22021}

ISSN: 2541-1667 (print); 2541-1675 (online)

emosinya masih belum bisa terkcontrol dan akhirnya hanya akan menyebabkan pertikaian dan muncul lagi akhlak negatif.

Dengan kepercayaang tinggi orang yang mencari ilmu itu tidak meninggalkan satu vak dari ilmu-ilmu yang terpuji, dan tidak pula salah satu macam-macamnya kecuali ia melihat padanya dengan pandangan yang menilik kepada tujuan dan penghabisannya. Kemudian jika ia masih ada umur agar memperdalaminya. Jika tidak maka ia sibuk (mengerjakan) mana yang lebih penting dari padanya dan menyempurnakannya, dan mengambil sedikit dari seluruh ilmu lainnya karena ilmu-ilmu itu di bantu membantu, sabagiannya berkaitan dengan sebagian yang lain. Maka dengan seperti itu peserta didik akan selalu percaya diri dengan kemampuan yang dapat menerima satu vak ilmu yang terpuji dan akan selalu menjaga akhlak positifnya.

\section{Tata Kesopanan atau akhlak seorang guru}

Mahmud Junus menghendaki sifat-sifat guru muslim sebagai berikut: Pertama, Menyayangi muridnya dan memerlakukan mereka seperti menyayangi anak sendiri. Kedua, Hendaklah guru memberi nasihat kepada muridnya seperti melarang mereka menduduki suatu tingkat sebelum berhak mendudukinya. Ketiga, Hendaklah guru memeringatkan muridnya bahwa tujuan menuntut ilmu adalah mendekatkan diri kepada tuhan, bukan untuk menjadi pejabat, untuk bermegahmegah atau bersaing. Kempat, Hendaklah guru melarang muridnya berkelekauan baik dengan cara lemah lembut, bukan dengan cara mencaci maki. Tidak boleh guru merendahkan pelajaran lain yang tidak diajarkannuya. ${ }^{30}$

Sifat-sifat guru yang telah di jelskan oleh Mahmud Junus tersebut tidak lah jauh berbeda dengan apa yang telah dijelaskan dipaprkan oleh Imam Al-Ghozali akan tetapi memiliki perbedaan yang kecil diantara keduanya yaitu, Imam Ghozali selalu menambahkan hadits-hadits atau ayat Al-Qur'an agar pendidik tersebut benar-benar harus melaksanakan tugasnya sebagai pendidik dengan benar. Seperti yang di bawah ini:

Belas kasih kepada orang-orang yang belajar dan memperlakukan mereka seperti memperlakukan anak-anaknya. Rasulullah saw bersabda:

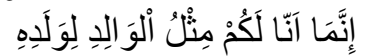

Artinya: "sesungguhnya saya bagimu adalah seperti orang tua kepada anakanaknya.

Beliau maksudkan adalah menyalamatkan mereka dari neraka akhirat, dan itu adalah lebih penting dari pada penyelamatan kedua orang tua kepada anaknya dari neraka dunia. Oleh karena itu jadilah guru, hak guru itu lebih besar dari pada hak kedua orang tua. Karena orang tua itu adalah sebab wujud (ada)nya sekarang dan kehidupan yang fana'(rusak), sedangkan guru adalah kehidupan yang kekal

Mengikuti pemilik syara' (nabi) Saw. Maka ia tidak upah karena memberitahukan ilmu, dan tidak bermaksud balasan dan terimakasih dengannya itu. Tetapi ia mengajar karena mencari keridhaan Allah Ta'ala dan mencari pendekatan diri kepadanya. Ia tidak melihat dirinya memberikan pemberian kepada mereka meskipun pemberian itu lazim atas mereka.

${ }^{30}$ Ahmad Tafsir, Ilmu pendidikan Islam, (Bandung: 2016), 132. 
Janganlah ia meninggalkan sedikitpun dari nasihat-nasihat guru. Demikian itu terhadap cegahan guru untuk memasuki tingkatan sebelum ia berhak, dan sibuk dengan ilmu yang samar sebelum selesai dari ilmu yang jelas. Jika diketahui dari batinnya bahwasannya ia belajar hanya karena dunia maka lihatlah kepada ilmu yang ia tuntut

Hal-hal yang halus dari pekerjaan mengajar, yaitu mencegah murid dari akhlak yang buruk dengan jalan sindiran, sedapat mungkin tidak dengan terang-terangan, dengan jalan kasih sayang, tidak dengan jalan membuka rasahasia. karena terangterangan itu merusak tirai kewibawaan dan menyebabkan berani menyerang karena perbedaan pendapat. Nabi Saw bersabda:

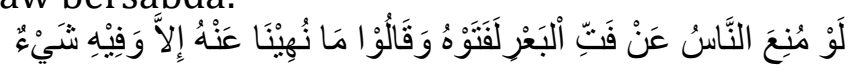

Artinya: "Seandainya manusia dilarang dari menghancurkan kotoran onta dengan jari niscaya mereka menghancurkannya dengan jari sambil berkata: "kami tidak dilarang dari padanya kecuali karena di dalamnya terdapat sesuatu".

Orang yang bertanggung jawab dengan di luar keahliannya di kalangan muridnya. Seperti guru ilmu bahasa biasanya memburukkan guru ilmu fiqih. Guru ilmu fiqih biasanya memburukkan guru ilmu hadits dan tafsir, dimana hal itu semata-mata menukil dan mendengar. Itu adalah peri keadaan orang-orang yang lemah dan tidak ada pemikiran akal padanya. Ini adalah akhlak yang tercela bagi para guru

Tentu dengan penjelasan Mahmud Junus tentang lima sifat seorang guru muslim tidaklah jauh berbeda dengan apa yang di paparkan Imam Al-ghazali seperti sifat guru muslim yang pertama yaitu menganggap dan mendidik peserta didik atau murid itu seperti anak mereka sendiri ketika mengasihinya, yang kedua yaitu hendaklah guru menasehati murid atau peserta didiknya agar melarang mereka menduduki suatu tingkat sebelum berhak mendudukinya Janganlah ia meninggalkan sedikitpun dari nasihat-nasihat guru dan Demikian itu terhadap cegahan guru untuk memasuki tingkatan sebelum ia berhak, dan sibuk dengan ilmu yang samar sebelum selesai dari ilmu yang jelas. Akan tetapi penjelasan-penejalasan selanjutnya ada sedikit perbedaan yaitu sifat guru muslim yang ketiga yaitu hendaklah guru memperingatkan muridnya agar menuntut ilmu adalah karena allah bukan untuk manjadi pejabat atau untuk bersaing, Imam Al-Ghazali menjelaskan bahwa guru harus mengajar dengan mencari keridhaan allah swt. Dengan penjelasan seperti ini tentu seorang gurulah yang harus mengajar dengan mencari keridhaan allah ta'ala agar murid bisa merasakan keikhlasan seorang guru tersebut ketika ia diajari olehnya, karena seorang murid mempunyai sebuah rasa yang mana bisa membedakan antara guru yang mengajar dengan mencari ridha allah dan guru yang hanya mengajar dengan asal-asalan.

Menurut Al- Ajari, para pendidik atau guru harus memiliki sifat akhlak agar Selalu beusaha untuk menambah masukan-masukan ilmu pengetahuan. Disini tidak memiliki sebuah kejelasan yaitu berusaha menambah masukan-masukan ilmu pengetahuan untuk siapa? Apakah peserta didik atau guru tersebut.

Maka dengan ini guru harus mengamalkan ilmunya kepada peserta didik agar ilmu pengetahuan peserta didik bertambah karena apabila seorag guru tidak mengamalkan maka ia mendustakan perkataanya karena ilmu itu diperoleh dengan 
pandangan hati sengakn pengalalman itu diperoleh dangan pandangan mata. Pada hal pemilik pandangan mata itu lebih banyak. Perumpamaan gurua yang membimbing terhadap murid yang dibimbing itu seperti ukiran dari tanah dan bayangan dari kayu maka bagaimanakah tanah itu akan terukir oleh sesuatu yang ada ukirannya, dan kapankah bayangan itu lurus sedangkan kayu itu sendiri bengkok? Oleh karena itu dikatakan pengertian itu: Allah Ta'ala berfirman

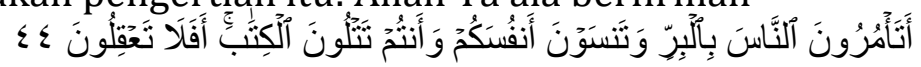

Artinya: "Mengapa kamu suruh orang lain (mengerjakan) kebaktian, sedang kamu melupakan diri (kewajiban)mu sendiri, padahal kamu membaca Al Kitab (Taurat)? Maka tidaklah kamu berpikir" (Al-Baqarah: 44).

Oleh karena itulah dosa orang 'alim dalam kemasiatamnya itu lebih besar dari pada dosa orang yang bodoh. Karena dengan ketergelincirannya itu tergelincirlah orang banyak dan mereka mengikuitnya. Padahal barang siapa yang menentukan perilaku yang buruk maka ia menanggung dosanya dan dosa orang yang melalukannya. Penjelasan singkatnya ialah janganlah sekali-sekali kamu tidak mengamalkan ilmu apa yang telah kau dapat dari apa yang kau cari ketika masa belajarmu karena setiap ilmu yang kau berikan pada peserta didik akan bermanfaat apabila kau menjadi seorang guru dan bermanfaat buat anakmu juga ketika menjadi orang tua.

\section{Tata kesopanan atau akhlak dengan teman, saudara, Lingkungan atau Masyarakat}

Sikap hormat kepada teman dan sahabat merupakan sikap terpuji dalam akhlak islam. Karena teman dan sahabat adalah orang yang kita ajak bergaul dalam kehidupan, berbuat baik terhadap teman dan sahabat sangat dianjurkan oleh rasulullah saw kepada para sahabatnya. Bahkan para sahabat rasulullah yang berasal dari mekkah (sahabat muhajirin), dipersaudarakan oleh rasulullah dengan para sahabat dari madinah (sahabat anshar). Tentu kita harus menjaga dan saling bermu'amalah kepada sesama kerabat akan tetapi kadang kala ketikan kita sedang melakukan hal tersebut bukan malah terjalin silaturahmi melainkan hanya dan selalu mengedepankan egonya masing-masing yakni tentang kekayaan dan kesuksesannya. Apabila salah satu dari mereka tidak memiliki keistemawaan maka yang (tidak mempunyai keistemwaan) itu lah yang akan dikucilkan dan tidak dihiraukan lagi.

Maka diperlukanlah tata cara untuk selalu menjaga persaudaraan di antara sesama teman dan saudara, memang sudah di jelaskan bahwa sikap hormat kepada sesama teman adalah akhlak terpuji akan tetapi di perlukan juga untuk mengetahui cara menjaga tali persaudaraan dengan baik. Disini Imam Al-Ghozali menjelaskan dalam bukunya Ihya Ulumiddin dalam tulisannya Umar Bin Khattab berkata: "wahai Rasulullah, allah tidak memperberat engkau apa yang engkau tidak kuasa atasnya Lalu nabi tidak suka yang demikian itu. Maka lelaki itu berkata: "belanjakanlah dan jangan takut akan kekurangan dari tuhan yang menguasai Arsy.

Dari dialog tersebut tentu kita dapat mengambil sebuah inti dari percekapan tersebut yaitu apabila kita ingin menyambung sebuah silaturahmi atau menjaga tali persaudaraan kita maka mari kita belanjakan sebagian dari hasil kita untuk membeli 


\section{DIROSAT \\ Journal of Islamic Studies \\ Volume 6, No. 22021}

ISSN: 2541-1667 (print); 2541-1675 (online)

sebuh buah tangan untuk saudara atau teman kita, maka dengan begitu saudara atau teman kita akan menyadari atas apa yang telah kita perbuat tersebut yakni memberiahukan keberhasilan kita secara halus kepada teman atau saudara kita.

Lingkungan sekitar kita seperti halnya tetangga yang dekat atau tetangga yang jauh tentulah mendapat sebuah hak, hak tersebut tentu berguna agar kita selalu menjalin hubungan yang baik. Dalam hal ini Imam Al-Ghozali menjelaskan tentang cara agar hubungan sesama tetangga selalu baik, Seseorang laki-laki masuk kepada Rasulullah saw. Untuk mengadukan tetangganya, lalu Rasulullah saw berkata: "Bersabarlah". Kemudian beliau bersabda kepadanya pada pengaduan yang ketiga atau orang-orang berjalan melewati orang itu dan bertanya: "apa yang terjadi padamu?" lalu dijawab: "ia disakiti tetangganya". Rawi berkata: lalu mereka mengucapkan: mudah-mudahan tetangga itu dikutuk allah". Kemudian tetangganya datang kepadanya dan berkata: "ambillah kembali harta bendamu, demi allah, saya tidak mengulangi lagi"

Dari percakapan tersebut tentu kita sebagai tetangga yang muslim kita harus mengetahui kadar dan kesanggupan tetangga kita apabila kita meminta bantuan kepadanya. Karena berkemungkinan tetangga kita juga sedang membutuhkan apa yang kita butuhkan juga, maka kita tidak boleh memaksakan kehendak kita sehingga tetangga kita merasa jengkel dan marah kepada kita.

\section{Kesimpulan}

Apabila kita ingin membentuk akhlak yang positif pada anak, maka kita harus membina dan mangejarkan kepada mereka tentang sebuah ilmu. Setelah itu kita arahkan ke mereka kepada ilmu yang yang terpuji agar mereka tidak terjerumus pada yang bathil. Untuk membentuk akhlak seorang peserta didik tentu yang harus kita lakukan ialah mensucikan jiwanya mereka dengan membiasakan mereka untuk selalu melakukan beribadah wajib seperti Shalat, Mengaji, Puasa dan ibadah-ibdah lainnya. Karena dengan seperti itu jiwa seorang anak akan selalu bernilai positif.

Sebuah pembentukan tentu memiliki berbagai cara, maka membentuk anak atau peserta didik kita harus mempunyai banyak cara agar mereka selalu berada dalam jalur yang kita inginkan. Dan itu kita harus mengetahui kadar perasaan atau bathiniyah mereka, agar ketika kita ajarkan sebuah ilmu atau kita arahkan tidak memiliki rasa yang negatif terhadap kita.

Tidak hanya peserta didik saja yang selalu di arahkan, seorang pendidik atau guru pun masih harus di ingatkan berulang kali, karena tidak menutup kemungkinan peserta didik yang memilki akhlak yang negatif telah mengikuti guru yang negatif juga. Untuk menyampaikan sebuah ilmu atau menerima ilmu sepatutnya kia harus membersihkan jiwa kita terlebih dahulu agar apa yang kita carai dan apa yang kita dapatkan menjadi sebuh manfaat yang besar semua umat manusia.

\section{Daftar Pustaka}

Abd. Rachman Assegaf, Filsafat Pendidikan Islam, (Jakarta: 2011)

Agus Wibowo, Gunawan, Pendidikan Karakter Berbasis Kearifan Lokal Di sekolah, (Yogyakarta: 2015) 
Ahmad Tafsir, Ilmu pendidikan Islam, (Bandung: 2016)

Al Qur an, Surah As Shaad ayat 71-72

Anwar Hafid, Jafar Ahiri, Pendais Haq, Konsep Dasar Ilmu Pendidikan, (Bandung: 2014)

Asmawati Suhid, Pengajaran Adab \& Akhalak Islam Dalam Membangunkan Modal Insan, (Jurnal Pengajian Umum Bil, Universiti Putra Malaysia: 2016)

Devi Arisanti, Implementasi Pendidikan Akhlak Mulia Di SMA Setia Dharma Pekanbaru, (Jurnal Al-Thariqah, Fakultas Tarbiyah dan Keguruan UIN Suska Riau: 2017)

Dharma kesuma, Cepi Triatna, Johar pernama, Pendidikan Karakter kajian teoritik dan Praktik di sekolah, (Bandung: 2013)

Didi Supardi, Abdul Ghofur, Mahbub Nuryadien, Konsep Pendidikan Moral Imam AlGhpzali dan Relevansinya dengan Pendidikan Agama Islam Di Indonesia, (Jurnal Al Tarbawi Al Haditsah IAIN Syekh Nurjati Cirebon: 2016)

Herawati, Pendidikan Akhlak Bagi Aanak Usia Dini, (Jurnal Pendidikan Islam UIN ArRainy Banda Aceh: 2017)

M. Djamal, Fenomena Kekerasan di Sekolah, (Yogyakarta: 2016)

M. Syamsul Ma'rif, Nilai-nilai Akhlak Dalam Suluk Linglung Dan relevansinya dengan pendidikan islam, (Jurnal Empirisma: 2015)

Moh. Abdai Rathony, Idzotun Naasyi'in, (Semarang: 1976)

Mohammad Rusli, Metode Penelitian Kuantitatif dan Kualitatif Berorientasi praktis, (Sumenep: 2013)

Mohammad takdir ilahi, Gagalnya pendidikan Karakter (Yogyakarta: 2014) https://infotekkom.wordpress.com/2009/05/02/hardiknas-kegagalanpendidikan-akhlak-dan-moral-bangsa/4/03/2018/12:38.

Muchtar, Konsep Pendidikan Akhlak dan Dakwah dalam Perspektif Dr. KH. Zakky Mubarak, MA, (Jurnal Studi Al-Qur'an; Membangun Tradisi Berfikir Qur'ani STAI Nahdhlatul Ulama Jakarta: 2016)

Muslimin, Problematika Pembelajaran Pendidikan Agama Islam dan Upaya Solusi Guru Agama Dalam pembinaannya di Sekolah, (Jural Ilmiah Pendidikan STAI Syekh maulana Qori Jambi: 2017),

Nurhattati Fuad, Manajemen Pendidikan Berbasis Masyarakat, (Jakarta: 2014)

Ramayulis, Dasar-Dasar Kependidikan, (Jakarta: 2015)

Ronald C. Heagy MSW, Dunia Yang Mulai Liar, (Jakarta: 2006)

Roziq Syaifuddin, Epistomologi Pendidikan Islam dalam kacamata Al-Ghazali dan Fazlur Rahman, (Makalah File PDF, UIN Maulana Malik Ibrahim Malang: 2012)

Sudarsono, Kenakalan Remaja: Prevensi, rehabilitasi, dan resosialisasi, (Jakarta: 2012) 